\title{
PENGARUH WAKTU PENANAMAN TERHADAP PERTUMBUHAN DAN HASIL BEBERAPA VARIETAS TANAMAN BAWANG MERAH (Allium ascalonicum L.)
}

\section{The Effect of Planting Time on Growth and Yield of Several Varieties of Shallot Plant (Allium ascalonicum L.)}

\author{
Yekti Sri Rahayu ${ }^{1}$ \\ ${ }^{1)}$ Fakultas Pertanian Universitas Wisnuwardhana \\ 1) e-mail: yektisr@ymail.com
}

\begin{abstract}
This study was conducted to evaluate the off-season planting time on growth and yield of three varieties of shallot plants in Sumbersekar Village, Malang Regency. Three shallot varieties were planted in Oktober 2009 (end of dry season), November 2009 (beginning of wet season), December 2009 (peak of wet season), as treatment for planting time. Data were recorded on leaf area, crop growth rate, number of shallot bulb per clump, bulb diameter, dry weight of shallot bulb per clump, harvest index, and productivity per plant. Data so collected were analyzed by ANOVA test, followed by Least Significant Difference Test at 5\% level. Super Philips, Bauji and Batu Ijo varieties that planted in Oktober 2009 (end of dry season) showed the yield of the bulb number higher than they planted in December 2009 (peak of wet season). Growth and yield of shallot were significantly higher in Oktober 2009 planting (the end of dry season planting) followed by the November 2009 planting (beginning of wet season) than in the late planting December 2009 (peak of wet season. Batu Ijo variety, generally, showed growth and yield better than Super Philips and Bauji varieties.
\end{abstract}

Key word: shallot, off-season planting

\begin{abstract}
ABSTRAK
Penelitian ini dilaksanakan untuk mengevaluasi waktu penanaman di luar musim terhadap pertumbuhan dan hasil dari tiga varietas tanaman bawang merah, di desa Sumbersekar, kabupaten Malang. Tiga varietas tanaman bawang merah ditanam pada Oktober 2009 (akhir musim kemarau), November 2009 (awal musim hujan) dan Desember 2009 (puncak musim hujan) sebagai perlakuan waktu penanaman. Data yang dicatat meliputi luas daun, laju pertumbuhan tanaman (Crop Growth Rate), jumlah umbi per rumpun, rata-rata diameter umbi panen per rumpun $(\mathrm{cm})$, berat kering (matahari) umbi per rumpun (g/rumpun), indeks panen dan produksi tanaman (ton/ha). Data yang dikumpulkan dianalisis dengan analisis ragam pada taraf 5\%, dan apabila terdapat pengaruh nyata dilanjutkan dengan Uji Beda Nyata Terkecil (BNT) pada taraf 5\%. Pengamatan penunjang dilakukan terhadap kondisi cuaca selama penelitian. Varietas Super Philips, Bauji dan Batu Ijo yang ditanam pada bulan Oktober 2009 (akhir musim kemarau) mampu menghasilkan jumlah umbi yang lebih banyak dibanding ketika ditanam di puncak musim hujan (Desember 2009). Secara umum pertumbuhan dan hasil tanaman bawang merah yang ditanam pada akhir musim kemarau, menunjukkan hasil
\end{abstract}


yang lebih baik pada luas daun, laju pertumbuhan tanaman, diameter umbi, bobot kering (matahari) umbi per rumpun, dan produksi tanaman per hektar dibanding jika ditanam lebih lambat pada puncak musim hujan. Varietas Batu Ijo secara umum menunjukkan pertumbuhan dan hasil yang lebih baik dibanding varietas Super Philips dan Bauji.

Kata kunci: bawang merah, penanaman di luar musim

\section{PENDAHULUAN}

Bawang merah adalah satu dari komoditas sayuran unggulan di Jawa Timur yang sangat fluktuatif harga maupun produksinya. Hal ini terjadi karena pasokan produksi yang tidak seimbang antara hasil panen pada setiap musimnya. Produksi bawang merah yang melimpah biasa dijumpai pada saat musim kemarau, namun harga bawang merah pada umumnya jatuh pada musim ini. Sebaliknya pada saat musim hujan, produksi bawang merah umumnya menurun, diikuti dengan harga yang tinggi.

Untuk mencapai hasil dan pertumbuhan yang maksimal, selain ditentukan oleh faktor genetik, juga dipengaruhi seberapa baik tanaman mampu beradaptasi dengan kondisi lingkungan dimana tanaman tumbuh (Doorenbos dan Kassam, 1979).. Umumnya tanaman bawang merah ditanam di musim kemarau. Namun di beberapa sentra produksi bawang merah, penanaman bawang merah tidak mengenal musim dan dapat ditanam kapan saja dengan sistem budidaya yang intensif. Masalah utama usahatani bawang merah bila penanaman di luar musim adalah tingginya resiko kegagalan panen (Baswarsiati et al., 1997). Tingginya resiko kegagalan panen tersebut disebabkan karena faktor pembatas yang berkaitan dengan lingkungan tumbuh yang kurang menguntung-kan. Diantaranya yaitu curah hujan yang terlalu tinggi dapat meningkatkan serangan terhadap hama dan penyakit penting pada bawang merah. Oleh karena itu diperlukan pemilihan waktu tanam yang tepat jika menginginkan penanaman di luar musim agar tanaman masih memberikan hasil yang baik. Pada percobaan ini diuji 3 waktu penanaman di luar musim yaitu bulan Oktober (dengan asumsi akhir musim kemarau), bulan November (awal musim hujan) dan bulan Desember (puncak musim hujan).

Selain memperhatikan pemilihan waktu penanaman, budidaya yang intensif juga memperhatikan pemilihan varietas yang akan digunakan untuk penanaman di luar musim. Dalam hal ini beberapa varietas tanaman yang akan ditanam memiliki karakteristik agroekologi tertentu, misalnya pada tanaman bawang merah varietas Super Philip dan Batu Ijo yang dapat ditanam pada dataran rendah hingga tinggi, selama ini sering ditanam pada musim kemarau. Sehingga perlu diketahui, apabila penanamannya dilakukan di luar musim apakah akan mempengaruhi pertumbuhan dan produksinya. Begitu pula pada varietas lain dari tanaman bawang merah yaitu Bauji, yang selama ini lebih dikenal sebagai varietas dataran rendah di daerah asalnya Nganjuk, menarik untuk diketahui pertumbuhan dan produksinya jika ditanam di daerah Malang dimana kondisi agroekologinya berbeda.

Penelitian ini dilakukan untuk mengetahui pertumbuhan dan produksi tiga varietas bawang merah ketika ditanam pada waktu tanam yang berbeda. 


\section{BAHAN DAN METODE}

Penelitian dilaksanakan di desa Sumbersekar, Dau, Kabupaten Malang, dengan jenis tanah inceptisol, dan ketinggian tempat sekitar $610 \mathrm{~m} \mathrm{dpl}$, pada bulan Oktober 2009 sampai dengan bulan Februari 2010.

Bahan-bahan yang digunakan antara lain umbi bibit bawang merah varietas Bauji, Super Philip, dan Batu Ijo, pupuk kandang, pupuk ZA, pupuk SP36, pupuk KCl, dan Dithane M-45, Dicarzol 25 SP. Alat-alat yang digunakan antara lain LAM, jangka sorong, cangkul, sabit, kored, gembor, penggaris, meteran, oven, timbangan, pisau, dan timbangan digital.

Penelitian menggunakan Rancangan Petak Terbagi. Masingmasing kombinasi perlakuan diulang sebanyak tiga kali. Waktu penanaman sebagai petak utama, terdiri 3 level yaitu: (P1) Oktober 2009 (akhir musim kemarau), (P2) November 2009 (awal musim hujan), (P3) Desember 2009 (musim hujan). Varietas bawang merah sebagai anak petak, terdiri dari 3 level yaitu: (B1) Varietas Super Philip, (B2) Varietas Bauji, (B3) Varietas Batu ijo.

Pengamatan terhadap pertumbuhan dan produksi tanaman meliputi, luas daun, laju pertumbuhan tanamn/Crop Growth Rate (CGR), jumlah umbi per rumpun, rata-rata diameter umbi panen per rumpun $(\mathrm{cm})$, berat kering (matahari) umbi per rumpun (g/rumpun), indeks panen dan produksi tanaman (ton/ha). Pengamatan penunjang dilakukan terhadap kondisi cuaca selama penelitian.

Data yang diperoleh dianalisis dengan analisis sidik ragam. Jika terdapat pengaruh nyata dilanjutkan pengujian dengan Uji BNT untuk mengetahui perbedaan antar perlakuan pada taraf $5 \%$.

\section{HASIL DAN PEMBAHASAN}

\section{Pertumbuhan Tanaman}

Hasil analisis sidik ragam menunjukkan bahwa secara umum waktu tanam dan varietas tidak menunjukkan interaksi nyata terhadap luas daun dan laju pertumbuhan tanaman.

Tabel 3. Luas daun tanaman bawang merah akibat perlakuan waktu tanam dan varietas pada berbagai umur pengamatan

(Table 3. Leaf area of shallot plants caused by the treatment time of planting and varieties of plants at various monitoring time)

\begin{tabular}{ccccccc}
\hline & \multicolumn{7}{c}{ Luas daun $\left(\mathrm{cm}^{2}\right)$ pada umur ke- $(\mathrm{hst})$} \\
\cline { 2 - 7 } Perlakuan & 21 & 28 & 35 & 42 & 49 & 56 \\
\hline Waktu Tanam & & & & & & \\
Oktober & $205.06 \mathrm{a}$ & $281.89 \mathrm{~b}$ & $802.56 \mathrm{~b}$ & $659.61 \mathrm{~b}$ & $568.39 \mathrm{~b}$ & $282.33 \mathrm{c}$ \\
November & $205.50 \mathrm{a}$ & $299.50 \mathrm{~b}$ & $600.00 \mathrm{a}$ & $368.50 \mathrm{a}$ & $166.83 \mathrm{a}$ & $143.06 \mathrm{~b}$ \\
Desember & $144.78 \mathrm{a}$ & $164.50 \mathrm{a}$ & $609.28 \mathrm{a}$ & $354.83 \mathrm{a}$ & $133.67 \mathrm{a}$ & $108.61 \mathrm{a}$ \\
\hline BNT 5\% & tn & 45.15 & 132.51 & 117.12 & 43.57 & 20.51 \\
\hline Varietas & & & & & & \\
Super Philips & $196.97 \mathrm{~b}$ & $281.00 \mathrm{~b}$ & $657.33 \mathrm{~b}$ & $443.72 \mathrm{a}$ & $303.22 \mathrm{a}$ & $183.17 \mathrm{a}$ \\
Bauji & $151.03 \mathrm{a}$ & $200.67 \mathrm{a}$ & $572.94 \mathrm{a}$ & $428.39 \mathrm{a}$ & $267.11 \mathrm{a}$ & $155.17 \mathrm{a}$ \\
Batu Ijo & $207.33 \mathrm{~b}$ & $264.22 \mathrm{~b}$ & $781.56 \mathrm{c}$ & $510.83 \mathrm{a}$ & $298.56 \mathrm{a}$ & $195.67 \mathrm{a}$ \\
\hline BNT 5\% & 35.40 & 34.1 & 76.02 & tn & tn & tn \\
\hline
\end{tabular}


Angka-angka pada kolom yang sama dan didampingi dengan huruf yang sama pada masing-masing perlakuan menunjukkan tidak berbeda nyata berdasarkan uji BNT pada taraf 5\%, hst (hari setelah tanam), tn (tidak nyata)

\section{Luas daun}

Secara umum penanaman pada bulan Oktober 2009 (akhir musim kemarau) menghasilkan luas daun tertinggi dibanding dua waktu tanam lainnya (Tabel 3). Penanam- an bawang merah di luar musim khususnya di akhir musim kemarau sebelum memasuki puncak musim didukung oleh kondisi lingkungan yang cukup baik diantaranya rata-rata suhu harian yang cukup, ditunjang dengan intensitas radiasi matahari yang tinggi pula (Lampiran 1) sehingga tanaman dapat memanfaatkan radiasi matahari untuk mengoptimalkan hasil fotosintesis dan didistribusikan pada pertumbuhan vegetatif tanaman yang lebih optimal. Anisuzzaman et al. (2009) mengungkapkan bahwa suhu yang menguntungkan dan hari-hari yang cerah (intensitas matahari cukup) mendukung pertumbuhan vegetatif maksimum, sementara hujan yang berlebih dapat menyebabkan kelembaban tanah terlalu tinggi dan merusak pertumbuhan vegetatif.

Secara terpisah varietas Super Philips dan Batu Ijo pada pengamatan umur 28 dan 35 hari menghasilkan luas daun yang lebih tinggi dibanding varietas Bauji, sedangkan pada pengamatan umur 42 hari hingga mendekati panen luas daun dari tiga varietas tidak berbeda nyata. Varietas Super Philips adalah varietas introduksi yang sudah lama ditanam oleh petani di daerah Malang, sementara varietas Batu Ijo merupakan varietas lokal asal Batu dan dapat ditanam baikpada musim kemarau maupun musim hujan (Baswarsiati, 2009), sehingga kedua varietas tersebut mampu beradaptasi di lingkungan setempat dengan baik.

\section{Laju Pertumbuhan Tanaman atau Crop Growth Rate (CGR)}

Secara umum tidak terjadi interaksi antara waktu tanam dan varietas terhadap laju pertumbuhan tanaman (crop growth rate) (Tabel 4). Diawal pertumbuhan laju pertumbuhan tanaman bawang merah yang ditanam pada 3 waktu tanam tidak berbeda nyata, sementara pada umur 49-56 hari, laju pertumbuhan tanaman bawang merah yang ditanam di akhir musim kemarau lebih tinggi dibanding dua waktu tanam lainnya. Laju pertumbuhan tanaman lebih tinggi ketika ditanam di akhir musim kemarau, dikarenakan sumber-sumber lingkungan seperti ratarata suhu harian masih lebih hangat, radiasi matahari cukup tinggi dan curah hujan rendah (Lampiran 1) sehingga tanaman dapat memanfaatkan hari-hari hangat tersebut untuk meningkatkan metabolisme tanaman selama pertumbuhan vegetatifnya maupun generatifnya. Krontal et al. (2000, dalam Rabinowitch dan Kemenetsky, 2002) mengungkapkan bahwa suhu lingkungan selama pertumbuhan nyata sekali mem-pengaruhi pertumbuhan vegetatif tanaman bawang merah.

Sementara ketika ditanam di puncak musim hujan, dimana rata-rata curah hujan sangat tinggi dan suhu harian juga menurun (Lampiran 1) dapat mengakibatkan metabolisme tanaman menjadi lambat sehingga laju 
pertumbuhan tanaman kurang optimal. Menurut Rosliani et al. (2005) curah hujan yang terlalu tinggi (diatas 200 $\mathrm{mm} / \mathrm{bulan}$ ) akan menyebabkan ketersediaan air yang berlebihan yang dapat menghambat proses fotosintesis untuk pertumbuhan tanaman.

Tabel 4. Laju pertumbuhan tanaman bawang merah akibat perlakuan waktu tanam dan varietas pada berbagai umur pengamatan

(Table 4. Shallot crop growth rate (CGR) caused by treatment time of planting and varieties at various monitoring time)

\begin{tabular}{cccccc}
\hline & \multicolumn{5}{c}{ Crop Growth Rate $\left(\right.$ CGR) $\left(\right.$ gm $^{-2}$ hari $\left.^{-1}\right)$, pada kisaran umur } \\
\cline { 2 - 6 } Perlakuan & $14-21$ & $28-35$ & $35-42$ & $42-49$ & $49-56$ \\
\hline Waktu Tanam & & & & & \\
Oktober & $1.821 \mathrm{a}$ & $6.377 \mathrm{a}$ & $8.324 \mathrm{a}$ & $7.318 \mathrm{a}$ & $3.294 \mathrm{c}$ \\
November & $1.547 \mathrm{a}$ & $5.849 \mathrm{a}$ & $6.809 \mathrm{a}$ & $5.887 \mathrm{a}$ & $2.573 \mathrm{~b}$ \\
Desember & $1.683 \mathrm{a}$ & $5.121 \mathrm{a}$ & $6.786 \mathrm{a}$ & $5.155 \mathrm{a}$ & $1.081 \mathrm{a}$ \\
\hline BNT 5\% & tn & tn & tn & tn & 0.364 \\
\hline Varietas & & & & & \\
Super Philips & $1.636 \mathrm{ab}$ & $5.518 \mathrm{a}$ & $7.267 \mathrm{a}$ & $6.163 \mathrm{a}$ & $2.464 \mathrm{a}$ \\
Bauji & $1.954 \mathrm{~b}$ & $5.503 \mathrm{a}$ & $6.838 \mathrm{a}$ & $5.897 \mathrm{a}$ & $2.210 \mathrm{a}$ \\
Batu Ijo & $1.461 \mathrm{a}$ & $6.326 \mathrm{a}$ & $7.813 \mathrm{a}$ & $6.301 \mathrm{a}$ & $2.273 \mathrm{a}$ \\
\hline BNT 5\% & 0.357 & tn & tn & tn & tn
\end{tabular}

Angka-angka pada kolom yang sama dan didampingi dengan huruf yang sama pada masing-masing perlakuan menunjukkan tidak berbeda nyata berdasarkan uji BNT pada taraf 5\%, hst (hari setelah tanam), tn (tidak nyata)

Tabel 5. Jumlah umbi bawang merah per rumpun akibat interaksi waktu tanam dan varietas

(Table 5. number of sahllot bulbs per clump caused by interaction between planting time and variety)

\begin{tabular}{c|ccc}
\hline \multirow{2}{*}{ Varietas } & \multicolumn{3}{|c}{ Waktu Tanam } \\
\cline { 2 - 4 } & Oktober & November & Desember \\
\hline Super Philips & $13.72 \mathrm{e}$ & $10.55 \mathrm{~d}$ & $5.43 \mathrm{a}$ \\
Bauji & $13.82 \mathrm{e}$ & $10.78 \mathrm{~d}$ & $6.60 \mathrm{~b}$ \\
Batu Ijo & $6.22 \mathrm{~b}$ & $7.43 \mathrm{c}$ & $4.78 \mathrm{a}$ \\
\hline BNT 5\% & \multicolumn{3}{|}{}
\end{tabular}

Angka-angka yang didampingi huruf sama menunjukkan tidak berbeda nyata berdasarkan uji BNT pada taraf 5\%.

\section{Komponen Hasil}

Hasil analisis sidik ragam menunjukkan bahwa perlakuan waktu tanam dan varietas menunjukkan interaksi nyata terhadap jumlah umbi, tetapi tidak menunjukkan interaksi nyata terhadap diameter umbi, bobot kering umbi indeks panen dan produksi tanaman per hektar.

\section{Jumlah umbi panen per rumpun}

Hasil analisis ragam menunjukkan terdapat interaksi nyata antara perlakuan waktu tanam dan 
varietas bawang merah terhadap ratarata jumlah umbi panen per rumpun.

Respon jumlah umbi masingmasing varietas pada waktu tanam yang berbeda menunjukkan bahwa secara umum ketiga varietas menghasilkan jumlah umbi yang sedikit ketika ditanam di puncak musim hujan, hal ini dikarenakan resiko terjadinya busuk umbi sangat besar ketika dipanen pada saat curah hujan masih sangat tinggi pada bulan Februari 2009 (Gambar 3). Ketiga varietas yang ditanam pada akhir musim kemarau jumlah umbi yang dihasilkan rata-rata lebih bagus dibanding jika ditanam lebih lambat pada awal musim hujan dan puncak musim hujan. Pertumbuhan vegetatif tanaman bawang merah yang optimal selama ditanam diakhir musim kemarau, dapat mendukung alokasi hasil yang optimal kepada komponen hasil tanaman yaitu umbi. Hal ini sejalan dengan hasil penelitian Krontal et al. (2000 dalam Rabinowitch dan Kamenetsky, 2002) bahwa waktu penanaman dan temperatur lapang mempengaruhi waktu pembungaan dan jumlah umbi pada tanaman bawang merah.

\section{Diameter Umbi, Bobot kering (matahari) umbi per rumpun, Indeks panen dan Produksi tanaman per ha}

Hasil analisis ragam menunjukkan tidak terdapat interaksi nyata antara perlakuan waktu tanam dan varietas bawang merah terhadap ratarata diameter umbi panen per rumpun, bobot kering (matahari) umbi per rumpun.

Rata-rata diameter umbi tanaman bawang merah terbaik diperoleh ketika ditanam pada akhir musim kemarau dibanding jika ditanam pada awal musim hujan, dan terendah jika ditanam pada puncak musim hujan. Hal ini karena didukung dengan kondisi lingkungan yang lebih baik dimana ratarata suhu harian yang relatif tinggi sebelum memasuki puncak musim hujan dapat meningkatkan metabolisme tanaman yang dapat berpengaruh pada pertumbuhan dan perkembangan tanaman yang lebih baik sehingga hasil diameter umbi juga akan lebih maksimal jika ditanam sebelum memasuki musim hujan. Jenkins (1954 dalam Rabinowitch dan Kamenetsky, 2002) mengungkapkan bahwa induksi perkembangan umbi secara relatif terjadi sebagai respon terhadap temperatur tinggi selain terhadap fotoperiod. Proses dimulai dengan perpanjangan dan pembengkakan dari pelepah daun dan tunas daun muda dari masing-masing tunas lateral individu, kemungkinan berkaitan dengan pembesaran sel (Brewster, 1994). Sementara pengaruh masing-masing varietas menunjukkan varietas Batu ijo memiliki diameter umbi yang lebih besar yaitu $2.02 \mathrm{~cm}$ dibanding varietas super Philips dan Bauji yang sekitar 1.62 dan $1.48 \mathrm{~cm}$ secara berturut-turut, hal tersebut dikarenakan faktor genetik dari masing-masing varietas.

Tabel 10. Diameter Umbi, Berat Kering Umbi, Indeks Panen, dan Produksi tanaman Bawang Merah per Hektar Akibat Perlakuan Waktu Tanam dan Varietas Saat Panen

(Table 10. Bulb Diameter, Bulb Dry Weight, Harvest Index, and Shallot Crop Production per Hectare Due to Treatment Time of Planting and Varieties at Harvest)

\begin{tabular}{c|c|c|c|c}
\hline Perlakuan & $\begin{array}{c}\text { Diameter } \\
\text { umbi } \\
(\mathrm{cm} / \text { rumpun })\end{array}$ & $\begin{array}{c}\text { Bobot kering } \\
\text { (matahari) } \\
\text { umbi } \\
\text { (gram/rumpun) }\end{array}$ & $\begin{array}{c}\text { Indeks } \\
\text { Panen } \\
(\%)\end{array}$ & $\begin{array}{c}\text { Produksi } \\
\text { tanaman } \\
\text { (ton/ha) }\end{array}$ \\
\hline $\begin{array}{c}\text { Waktu Tanam } \\
\text { Oktober }\end{array}$ & $1.96 \mathrm{c}$ & $49.65 \mathrm{c}$ & $0.939 \mathrm{a}$ & $12.41 \mathrm{c}$
\end{tabular}




\begin{tabular}{c|c|c|c|c} 
November & $1.65 \mathrm{~b}$ & $39.59 \mathrm{~b}$ & $0.941 \mathrm{a}$ & $9.90 \mathrm{~b}$ \\
Desember & $1.50 \mathrm{a}$ & $31.26 \mathrm{a}$ & $0.929 \mathrm{a}$ & $7.82 \mathrm{a}$ \\
\hline BNT 5\% & 0.07 & 6.29 & tn & 1.57 \\
\hline Varietas & & & & \\
Super Philips & $1.62 \mathrm{~b}$ & $39.17 \mathrm{a}$ & $0.941 \mathrm{~b}$ & $9.79 \mathrm{a}$ \\
Bauji & $1.48 \mathrm{a}$ & $37.30 \mathrm{a}$ & $0.923 \mathrm{a}$ & $9.32 \mathrm{a}$ \\
Batu Ijo & $2.02 \mathrm{c}$ & $44.03 \mathrm{~b}$ & $0.944 \mathrm{~b}$ & $11.01 \mathrm{~b}$ \\
\hline BNT 5\% & 0.08 & 4.39 & 0.011 & 1.10 \\
\hline
\end{tabular}

Angka-angka yang didampingi huruf sama pada masing-masing perlakuan menunjukkan tidak berbeda nyata berdasarkan uji BNT pada taraf 5\%.

Hasil berat kering umbi per rumpun dan produksi tanaman per hektar menunjukkan pengaruh dari masing-masing perlakuan, dimana hasil umbi terbaik diperoleh ketika tanaman bawang merah ditanam pada akhir musim kemarau yang rata-rata menghasilkan berat umbi sebesar 49.65 $\mathrm{g} /$ rumpun dan produksi tanaman sebesar 12.41 ton/ha dibanding jika ditanam awal musim hujan dan puncak musim hujan yang menghasilkan rata-rata berat umbi 39.59 dan $31.26 \mathrm{~g} /$ rumpun dan produksi tanaman sebesar 9.90 dan 7.82 ton/ha secara berturut-turut. Hal ini karena didukung pertumbuhan tanaman yang lebih bagus saat tanaman bawang merah ditanam pada akhir musim kemarau (sebelum memasuki musim penghujan), dibanding jika ditanam awal musim hujan dan puncak musim hujan. Produksi tanaman menunjukkan penurunan yang signifikan ketika ditanam di puncak musim hujan, hal ini dikarenakan meskipun tanaman mampu memproduksi umbi, namun karena curah hujan cukup tinggi menyebabkan banyak umbi yang busuk ketika dipanen. Hasil tersebut sejalan dengan hasil yang diperoleh pada bawang bombay hasil penelitian Mondal (1985, dalam Brewster, 2008) dimana tanaman bawang bombay yang ditanam lebih lambat pada tanggal 21 April hasilnya berkurang dibanding yang ditanam lebih awal pada tanggal 15 Maret, dengan hasil umbi yang ditanam pada tanggal 21 April adalah $0.73 \mathrm{~kg} / \mathrm{m} 2$ dan yang ditanam pada tanggal 15 Maret menghasilkan umbi $1.04 \mathrm{~kg} / \mathrm{m} 2$. Sementara itu dari ketiga varietas yang ditanam, varietas Batu ijo menghasilkan umbi per rumpun dan per hektar yang lebih tinggi dibanding varietas Super Philips dan Bauji. Hal ini tentu berkaitan dengan pengaruh genetik dari masing-masing varietas. Perbedaan kultivar menunjukkan respon yang berbeda terhadap produksi umbi per rumpun, yang pada akhirnya berpengaruh terhadap produksi dan hasil umbi keseluruhan (Cheema et al., 2003).

Hasil pengamatan terhadap indeks panen tanaman bawang merah menunjukkan bahwa waktu tanam tidak berpengaruh nyata terhadap indeks panen, sementara dari ketiga varietas bawang merah, varietas Super Philips dan Batu Ijo menunjukkan indeks panen yang lebih besar dibanding varietas Bauji. Hal tersebut berkaitan dengan pengaruh genetik dari masing-masing varietas. Namun secara umum indeks panen dari ketiga varietas lebih dari 0.7 yang meunjukkan indeks panen terbaik bagi tanaman. Menurut Brewster (1997), nilai indeks panen yang baik untuk tanaman bawang merah tidak kurang dari 0.7. Hal tersebut 
menunjukkan bahwa fotosintat lebih banyak digunakan untuk disimpan didalam umbi daripada untuk pertumbuhan dan perkembangan organ lainnya (Hamdani, 2008) .

\section{KESIMPULAN}

Varietas Super Philips, Bauji dan Batu Ijo yang ditanam pada bulan Oktober 2009 (akhir musim kemarau) mampu menghasilkan jumlah umbi yang lebih banyak dibanding ketika ditanam di puncak musim hujan (Desember 2009). Secara umum pertumbuhan dan produksi tanaman bawang merah yang ditanam pada akhir musim kemarau, menunjukkan hasil yang lebih baik pada panjang tanaman, luas daun, laju pertumbuhan tanaman, diameter umbi, bobot kering (matahari) umbi per rumpun, dan produksi tanaman per hektar dibanding jika ditanam lebih lambat pada puncak musim hujan. Varietas Batu Ijo secara umum menunjukkan pertumbuhan dan hasil yang lebih baik dibanding varietas Super Philips dan Bauji.

Lampiran 1. Data cuaca di Malang dari bulan Oktober 2009 - Pebruari 2010 (Sumber: Badan Meteorologi dan Geofisika Stasiun Klimatologi Karangploso Malang)

(Climatological data at Malang regency, from October 2009 to February 2010 (Source: meteorological and geophysical agency climatology stations Karangploso Malang))

\begin{tabular}{ccccc}
\hline $\begin{array}{c}\text { Bulan } \\
\text { (Month) }\end{array}$ & $\begin{array}{c}\text { Suhu } \\
(\text { Temperature }) \\
{ }^{\circ} \mathrm{C}\end{array}$ & $\begin{array}{c}\text { Curah Hujan } \\
\text { (Rainfall) } \\
\text { mm/bulan } \\
\text { (month) }\end{array}$ & $\begin{array}{c}\text { Jumlah } \\
\text { Hari } \\
\text { Hujan } \\
\text { day with } \\
\text { rainfall) }\end{array}$ & $\begin{array}{c}\text { Intensitas Radiasi } \\
\text { Matahari (Intensity of } \\
\text { solar radiation) } \\
\text { Cal/cm }{ }^{2} . \text { hari }\end{array}$ \\
\hline $\begin{array}{c}\text { Oktober 2009 } \\
\text { (October 2009) }\end{array}$ & 24.4 & 34 & 9 & 380.1 \\
\hline $\begin{array}{c}\text { November 2009 } \\
\text { (November 2009) }\end{array}$ & 24.9 & 200 & 12 & 379.6 \\
\hline $\begin{array}{c}\text { Desember 2009 } \\
\text { (December 2009) }\end{array}$ & 24.3 & 225 & 20 & 379.5 \\
\hline $\begin{array}{c}\text { Januari 2010 } \\
\text { (January 2010) }\end{array}$ & 23.9 & 351 & 28 & 330.3 \\
\hline $\begin{array}{c}\text { Pebruari 2010 } \\
\text { (February 2010) }\end{array}$ & 24.0 & 218 & 23 & \\
\hline
\end{tabular}

\section{DAFTAR PUSTAKA}

Anisuzzaman,M. M. Ashrafuzzaman, M.R. Ismail, M.K. Uddin dan M.A. Rahim. 2009. Planting time and mulching effect on onion development and seed production. Afr.J.Biotechnol.8(3):412-416.
Baswarsiati dan S. Nurbanah. 1997. Teknik budidaya bawang merah di luar musim. Balai Pengkajian Teknologi Pertanian Karangploso. Instalasi Penelitian dan Pengkajian Teknologi Pertanian Wonocolo. pp.12.

Baswarsiati, L. Rosmahani, B. 
Nusantoro,R.D. Wijadi. 1997. Pengkajian paket teknik budidaya bawang merah di luar

musim. Prosiding Seminar Hasil Paket Penelitian/Pengkajian BPTP Karangploso.

. 2009. Budidaya bawang merah dan penanganan permasalahannya.

http://baswarsiati.wordpress.com/2 009/04/24/budidaya-bawang-

merah-dan-penanganan-

permasalahannya/

Brewster, J.L. 1994. Onions and other vegetable alliums. $\mathrm{CAB}$ International. Wallingford. UK. pp.236.

. 2008. Onions and other vegetable Alliums. $2^{\text {nd }}$ Edition .CAB International. Wallingford. UK. pp.432.

Cheema, K.L., Saeed, A., and Habib,M. 2003. Effect of sowing date on set size in various cultivars of Onion (Allium cepa L.). Int.J.Agri.Biol., 5(2):185-187.

Hamdani, J.S. 2008. Pertumbuhan dan hasil bawang merah kultivar Kuning pada status hara $\mathrm{P}$ total tanah dan dosis pupuk Fosfat yang berbeda. J.Agrikultura 19(1):42-49

Rabinowitch, H.D. and R. Kamenetsky. Shallot (Allium cepa, Agregatum Group) edited by Rabinowitch, H.D. and L. Curah. 2002. Allium crop science: Recent advances. CAB International.p. 409-430.

Rosliani,R., Suwandi, dan N. Sumarni. 2005. Pengaruh waktu tanam dan zat pengatur tumbuh Mepiquat klorida terhadap pembungaan dan pembijian bawang merah (TSS). J.Hort.15(3):192-198. 